\title{
Analisis Gemma Tulud Cruz tentang Teologi Bertahan Hidup di tengah Pandemi: Perspektif Teologi Asia
}

\author{
Gemma Tulud Cruz's Analysis of Theology of Survival in the Midst of a Pandemic:
}

An Asian Theological Perspective

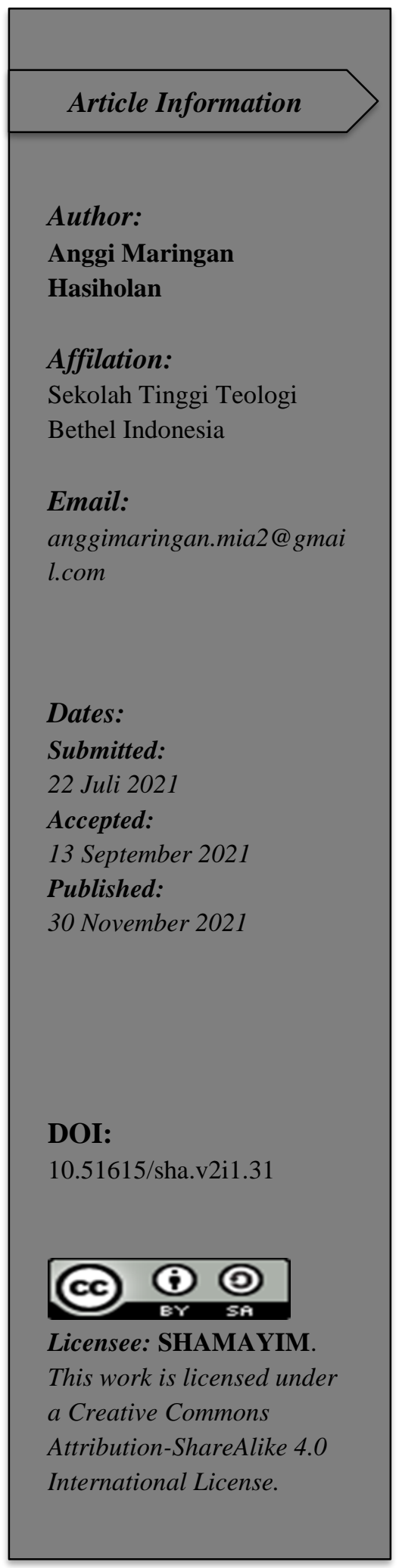

Abstract: Surviving under challenging situations and suffering is a natural act for someone who has hope. Because if not, then suicide is the chosen path. The Covid-19 pandemic to date has caused suffering for humans in all aspects throughout the world, predominantly in Asian countries. The question of how to deal with suffering and the implementation of salvation today is relevant for discussion. This article aims to reveal the particular way Asian people, according to Gemma Tulud Cruz's perspective in deal with suffering. The method used is qualitative exploratory with a focus on disclosing the thoughts of Gemma Tulud Cruz. The results show that Asian ways to survive are silence, humor, laughter, community storytelling, singing, and dancing. This can apply to a community that not bound by religion, ethnicity, and race. Of course, the main thing is faith and hope in the person of Jesus. This characteristic can be correlated with the context of survival in Indonesia in the face of suffering due to the COVID-19 pandemic.

Keywords: Gemma Tulud Cruz, Survival theology, Covid-19, suffering

Abstrak: Bertahan hidup dalam situasi sulit dan penderitaan adalah tindakan wajar yang dilakukan oleh seseorang yang memiliki pengharapan. Sebab jika tidak, maka bunuh diri adalah jalan yang dipilih. Pandemi covid-19 hingga saat ini melahirkan penderitaan bagi manusia dalam segala aspek di seluruh dunia, khususnya negara-negara Asia. Pertanyaan bagaimana menghadapi penderitaan itu dan implementasi keselamatan di masa kini menjadi relevan untuk didiskusikan. Artikel ini bertujuan untuk mengungkapkan cara khusus orang Asia menurut perspektif Gemma Tulud Cruz dalam menghadapi penderitaan. Metode yang digunakan adalah kualitatif eksploratif dengan fokus pengungkapan pemikiran Gemma Tulud Cruz. Hasil penelitian menunjukkan bahwa kekhususan dari cara orang Asia untuk bertahan hidup adalah dengan berdiam, humor dan tertawa, bercerita dalam komunitas, bernyanyi dan menari. Hal tersebut dilakukan dalam komunitas yang tidak tersekat agama, suku, dan ras. Tentu yang utama adalah iman dan pengharapan kepada pribadi Yesus. Ciri khas ini dapat dikorelasikan dengan konteks bertahan hidup di Indonesia dalam menghadapi penderitaan akibat pandemi covid-19.

Kata Kunci: Gemma Tulud Cruz, Teologi bertahan hidup, Covid-19, penderitaan 


\section{Pendahuluan}

Pandemi Covid-19 telah menjadi masalah besar bagi seluruh bangsa di seluruh dunia. Hingga saat ini belum ada bangsa yang berani mengklaim telah mampu menghadapi masalah ini secara tuntas. Bahkan di beberapa negara, keadaan ini semakin parah dengan kenaikan angka positif covid-19 secara drastis. Sebut saja India sebagai salah satu negara di Asia yang mengalami lonjakan jumlah terpapar Covid-19 dan angka kematian yang tinggi. Rumah sakit kewalahan karena tidak lagi memiliki ruangan untuk merawat pasien, tidak adanya oksigen untuk membantu pernapasan pasien yang mengalami gejala sesak nafas, bahkan tempat kremasi untuk membakar jenazah yang telah wafat tidak ada (Christiastuti, 2021). Demikian juga dengan kasus kenaikan di Malaysia, salah satu negara di Asia Tenggara yang mengalami rekor dalam kenaikan pasien kritis dan terancam nyawanya akibat pandemi ini (Yanwardhana, 2021).

Dilansir dari laman CNN Indonesia, terdapat beberapa negara yang terus mengalami tren kenaikan kasus positif dan angka kematian di Asia lainnya. Indonesia menjadi negara terdepan dalam daftar ini. Dilanjutkan dengan negara Bangladesh dan Thailand, selain negara India dan Malaysia yang telah dipaparkan di atas (Tim CNN Indonesia, 2021). Berbagai penyebab dari kenaikan ini disampaikan. World Health Organization (WHO) mengindikasikan bahwa penyebab dari lonjakan ini adalah akibat dari varian baru dari virus Covid-19 yang bermutasi dan semakin ganas. Alasan lain yang dilontarkan berkaitan dengan kepanikan dari masyarakat ketika mengetahui mengalami gejala penyakit ini. Demikian dengan para ahli kesehatan yang menyoroti kasus kenaikan akibat lingkungan yang padat penduduk sehingga mudah untuk tersebar dan tertular secara cepat (Septiani, 2021). Senada dengan itu, Sasongko melakukan rekapitulasi kenaikan jumlah covid diakibatkan pergerakan masif ketika perayaan hari-hari besar agama (Sasongko, 2021). Fakta ini menunjukkan bahwa penderitaan manusia akibat pandemi Covid-19 terus bergulir dan meningkan.

Menanggapi permasalah yang berkaitan dengan kehidupan manusia, pemerintah-pemerintah negara di Asia mengeluarkan kebijakan darurat. Pemerintah India melakukan lockdown, pemerintah Vietnam, Laos, Sri lanka, dan Malaysia memutuskan menutup semua kegiatan Pendidikan (Khoerunisa \& Noorikhsan, 2021). Demikian dengan Indonesia yang merasa perlu melakukan upaya penanggulangan yaitu salah satunya dengan tindakan Pembatasan Sosial Berskala Besar (PSBB) atau yang disebut juga Pemberlakuan Pembatasan Kegiatan Masyarakat (PPKM). Dalam rangka percepatan penanganan Covid19 (RI, 2020). PSBB tersebut meliputi peliburan sekolah dan tempat kerja, pembatasan jam masuk kantor, pembatasan kegiatan di tempat atau fasilitas umum, pembatasan kegiatan sosial budaya, pembatasan moda transportasi dan pembatasan kegiatan lainnya terkait aspek pertahanan dan keamanan. Termasuk pembatasan kegiatan keagamaan (Keputusan Presiden RI, 2020). Upaya yang dilakukan pemerintah telah maksimal dan terukur, tetapi tetap belum menyelesaikan penderitaan yang dialami oleh masyarakat secara umum.

Apakah serangkaian kebijakan ini dapat menanggulangi penderitaan masyarakat akan pandemi ini? Ternyata tidak sama sekali. Justru masalah dari bidang lain muncul. Bidang ekonomi terkena imbas yang besar. Masyarakat harus mengalami Pemutusan Hubungan Kerja (PHK) secara besar-besaran, investasi tidak dapat berjalan dengan baik, rendahnya sentimen investor terhadap pasar yang pada akhirnya membawa pasar ke arah cenderung negatif (Nasution et al., 2020), bisnis-bisnis tutup karena tidak sanggup untuk membayar karyawan dan daya beli masyarakat yang rendah (Velarosdela, 2020). Terlihat dengan jelas bahwa penderitaan demi penderitaan dialami masyarakat di Asia. Penderitaan seperti "teman" yang selalu bersama dalam realitas kehidupan. Dia menjadi bagian yang tidak dapat dilepaskan dengan mudah. 
Pil pahit yang dirasakan oleh negara-negara Asia pada dasarnya adalah "teman" yang selalu ada. Fakta ini tergambarkan dengan jelas dari penelitian panjang yang dilakukan Cruz tentang penderitaan yang dialami oleh wanita-wanita Asia yang melakukan migrasi untuk bertahan hidup. Cruz menyatakan bahwa Asia memiliki sejarah panjang migrasi permanen karena perdagangan, pekerjaan, pertukaran agama atau budaya. Pada masa prakolonial semenanjung Melayu, Indonesia dan Filipina merupakan wilayah yang ditandai dengan mobilitas penduduk dari berbagai etnis terutama melalui laut. Mobilitas ini dilakukan untuk mencari cara bagaimana bisa bertahan hidup dalam masalah (Cruz, 2004). Cruz secara mendalam menyoroti bagaimana para Wanita imigran dapat bertahan hidup (survive) dari penindasan berupa fisik dan verbal kepada para pembantu atau asisten rumah tangga (Cruz, 2006).

Cruz terus menyuarakan kehidupan Kristen yang melampaui batas, di mana Kekristenan mesti memenuhi seluruh kebutuhan manusia. Kebutuhan ini beragam berkaitan dengan kesejahteraan spiritual, emosional, psikologis dan material individu. Cruz mengidentifikasi agama memiliki peran multidimensi bagi perempuan migran Asia. Dia mencatat, "selain tertindas (rakyat) migran juga adalah orang-orang tercerabut dan agama banyak membantu mereka untuk mengatasi perpecahan dan diskontinuitas dalam hidup mereka (Cruz, 2006)." Tujuan Cruz dalam pekerjaan ini adalah untuk membuka jalan menuju sebuah teologi inklusif dan lebih relevan untuk perempuan dalam konteks Filipina. Teologi yang ramah terhadap insan-insan yang mengalami penderitaan.

Penulis memaparkan dan mengangkat konteks Asia dalam studi ini dikarenakan Asia memiliki ciri khas tersendiri dalam bangunan dan cara berteologinya. Asia sebagai benua terbesar (dalam ukuran dan populasi) dan tempat lahirnya sejumlah agama dunia, termasuk Kristen, tentu saja patut mendapat perhatian dari akademisi studi teologi. Studi agama yang ada selama ini juga lebih memilih agama-agama non-Kristen sebagai objek penelitian. Jadi, Kekristenan di Asia dibahas terlalu lama hanya di kalangan misionaris. Demikian diantara sejarawan gereja atau teolog misi dalam konteks ekspansi berkelanjutan Kristen "Barat" ke Timur (Wilfred, 2014). Itu sebabnya, dalam kajian teologi kontemporer, teologi Asia dimasukkan oleh Jan Aritonang karena perspektifnya yang khas dengan penderitaan (Aritonang, 2018). Penderitaan itu yang membawa kepada persatuan yang diartikulasikan oleh banyak komunitas (Clarke, 2012). Orang Asia tidak melihat penderitaan sebagai musuh yang dilawan secara pribadi, melainkan kebersamaan dalam komunitas yang saling terbuka.

Ketepatan mengangkat teologi Asia juga karena karakteristik yang terdapat didalamnya. Pasulu dalam Teologi-teologi Kontemporer menjelaskan terdapat empat karakteristik teologi Asia. Pertama, realitas Perang dan penderitaan yang berkaitan dengan sejarah masa lalu perang China setelah kejatuhan dinasti Qing pada tahun 1912 dan peristiwa Hiroshima-Nagasaki. Kedua, realitas kemiskinan yang parah. Negara-negara Asia tergolong sebagai negara miskin, bahkan Pasulu menyebut sebagai kemiskinan yang absolut. Di India terdapat kasta Dalit yang dalam sistem struktur masyarakat adalah kelompok paling miskin tetapi jumlahnya paling banyak. Ketiga, realitas keberagaman Tradisi Religius. Asia dengan Kekristenan yang minoritas berhadapan dengan agama-agama lain yang memiliki pengikut besar. Keempat, realitas ketidakadilan ganda bagi kaum wanita (Pasulu, 2016). Keempet karakteristik ini membangun pola berteologi Asia yang berbeda dan khas yang dapat mengidentifikasikan bagaimana seharusnya berteologi dalam konteks Asia.

Teologi Asia meskipun terbilang benih baru dalam kajian teologi kontemporer, tetapi yang ditawarkan oleh Cruz amat relevan dengan konteks negara-negara Asia yang sedang bergumul untuk keluar dari masalah pandemi Covid-19. Penulis menyatakan bahwa survival theology "ala" Cruz adalah jawaban terhadap keresahan penduduk Indonesia dalam menghadapi pergumulan Covid-19 di bidang ekonomi dan 
kesehatan. Karena pemikiran Cruz akan mengarah kepada pertanyaan fundamental umat yang beragama, siapa Tuhan bagi kita, dan bagaimana kita dapat memahami Tuhan, dalam konteks di mana kita terpinggirkan dan menderita?

Penelitian terkait pemikiran Gemma Tulud Cruz pernah dilakukan oleh Ahn yang menyoroti peran kekristenan dalam merespon migrasi di negara-negara maju (Ahn, 2019). Demikian dengan Heyer yang mengungkapkan tanggung jawab dan etika sosial gereja Katolik yang bersifat universal dalam melihat penderitaan kemiskinan. Heyer menegaskan agar gereja melakukan pertobatan dari dosa sosial yang menyebabkan kemiskinan dan ketimpangan terus terjadi hingga saat ini (Heyer, 2020). Kebaharuan dari penelitian ini adalah mengambil asas-asas penting dari pemikiran Cruz yang dikaitkan dengan penderitaan akibat Covid-19. Sebab melalui perjalanan migrasi yang diteliti Cruz, praktik keagamaan dapat bersifat konstruktif dalam menjawab kebutuhan individu dan masyarakat.

\section{Metode Penelitian}

Penelitian ini menggunakan metode kualitatif eksplanatory dengan subjek pembahasannya adalah penderitaan dan masalah akibat pandemi Covid-19. Penelitian ini mengeksplorasi variabel-variabel terkait hingga titik jenuh (komprehensif dari batasan variabel dan sumber literatur). Eksplanatory juga bersifat menjajaki temuan dan menjelajahi setiap kemungkinan yang ada karena pengetahuan awal tentang masalah masih minim bahkan tidak ada (Zaluchu, 2020). Prosedur penelitian yang penulis kerjakan dimulai dengan pengumpulan data. Data dikumpulkan dengan membangun konsep penderitaan dalam kacamata Alkitab dan kehidupan sosial masyarakat. Selanjutnya, penulis memahami pemikiran dari Gemma Tulud Cruz mengenai teologi bertahan hidup (survival Theology) dari berbagai sumber ilmiah. Setelah mendapatkan intisari dari pemikiran Cruz, penulis menghubungkan dengan tindakan-tindakan nyata yang dapat dilakukan oleh gereja di Indonesia ketika hidup dalam realitas sosial masyaakat yang memiliki penderitaan akibat pandemi Covid-19.

\section{Hasil dan Pembahasan \\ Hakikat Penderitaan}

Penderitaan tidak jarang ditemukan di negara-negara Asia. Meskipun diidentifikasikan sebagai negara-negara yang beragama. Namun, penderitaan menjamur di negara-negara Asia. Yewangoe mengungkapkan bahwa penderitaan yang terjadi dikarenakan kemiskinan. Terkait dengan faktor apa saja yang menyebabkan kemiskinan, dia mengemukakan terdapat 3 faktor sental mengapa bangsa di Asia mengalami kemiskinan. Pertama, aspek sosial politik. Negara Asia mengalami realitas penjajahan dari bangsa Barat yang membiakkan penindasan, pembangunan yang hanya terfokus kepada kota-kota, elite penguasa yang menindas rakyat kecil dan maraknya praktik korupsi oleh para pejabat pemerintahan. Kedua, faktor agama. Faktor ini terutama berasal dari ajaran atau dogma yang dianut oleh beberapa agama. Agama Budha lebih menekankan hidup dalam kontemplatif daripada keluar dari kemiskinan. Bagi mereka miskin bukanlah keadaan yang harus dihindari, melainkan diperlukan mengambil makna dari kemiskinan yang dialami. Lain halnya dengan agama Hindu yang memandang bahwa kemiskinan akibat dari karma yang diterima sebelum dirinya lahir ke dunia. Sedangkan agama-agama suku yang menjamur di negara Asia memiliki pandangan bahwa kemiskinan dan keberuntungan adalah pemberian dari Ilah mereka dan itu adalah "teman" yang berdampingan. Bahkan Kekristenan sendiri memiliki pandangan bahwa kedatangan Messias akan membawa kepada sukacita dan sejahtera surga. Tanpa perlu adanya usaha untuk mengubah 
keadaan mereka. Demikian dengan Agama Islam memandang bahwa kemiskinan adalah hukuman dan kehendak dari Allah sendiri. Negara Asia yang taat kepada ajaran Agama pun menerima realitas kemiskinan secara spiritual, dan minim berjuang keluar dari keadaan tersebut. Ketiga, faktor mentalitas masyarakat yang secara legowo menerima setiap penderitaan dan kemiskinan sebagai kehidupan yang harus dijalani (Yewangoe, 1996). Faktor yang di potret oleh Yewangoe merupakan keadaan nyata yang mengemuka dalam kehidupan masyarakat Asia.

Penderitaan adalah suatu keadaan yang menyulitkan dalam hati dan fisik (malum physicum) seseorang yang membuat manusia harus menjaga tubuhnya dengan baik, dan penderitaan akibat metafisik (malum metafisika). Sedangkan Leibniz menambahkan penderitaan akibat moral (malum morale) yang dapat diatasi oleh manusia itu sendiri (Hidayat, 2016). Alkitab menjelaskan bahwa penderitaan adalah dampak secara langsung dari dosa. Keadaan ini yang disebut oleh (Zaluchu, 2021) sebagai keadaan otomatis manusia yang tidak dapat dihindarkan karena dosa yang melahirkan kutuk kepada tanah (adamah). Ketika Adam jatuh ke dalam dosa dengan melanggar perintah yang Tuhan berikan, Allah mengutuk tanah yang membuat Adam harus mengalami kesusahan (itsavon) (Boersema et al., 2015). Sebab apabila manusia tetap dalam gambar dan rupa Allah, tidak mungkin mengalami penderitaan (Hasiholan, 2020). Tentu hal ini tidaklah mutlak bahwa semua kesulitan atau penderitaan akibat dosa. Bagaimana menilai penderitaan yang dialami oleh Ayub? Memang ketiga temannya mengidentifikasikan itu karena dosa Ayub. Sebab mereka menganut paham retribusi, yaitu jika kita hidup benar, maka akan diberkati. Tetapi jika kita hidup dalam dosa, maka kita mengalami penderitaan (Baker, 2008). Namun, Ayub mengalami penderitaan dikarenakan ujian yang diberikan kepada dia. Tong mengungkapkan hakikat penderitaan bagi orang percaya pada dasarnya adalah proses yang melahirkan buah-buah bermutu (Tong, 1999). Berbagai pandangan mengenai penderitaan ini membawa pemikiran orang percaya kepada realitas kesulitan dalam segala keberadaan manusia.

Ketika Yesus hidup dan bermasyarakat dengan orang-orang Yahudi, Dia menyaksikan sendiri penderitaan adalah "teman" yang selalu ada dalam konteks sosial masyarakat. Bahkan, murid-murid-Nya yang dipanggil untuk melayani juga dijanjikan mengalami penderitaan dengan memikul salib (Mat. 16:24). Salib adalah penderitaan menurut Bruce yang disebabkan bukan karena dosa, melainkan iman kepada Yesus. Petrus yang disalib terbalik di akhir hidupnya, Yohanes yang dibuang ke pulau Patmos setelah sebelumnya harus meminum racun mematikan, Filipus yang menurut sejarah gereja disalib (Bruce, 2013). Limasaputra menegaskan bahwa penderitaan adalah panggilan orang percaya yang sedang hidup dalam era the already and the not yet akan akhir zaman (Limasaputra, 2018). Dengan demikian, penderitaan pada masa kini tidak bisa dikaitkan secara langsung kepada akibat dari dosa yang sudah atau sedang dilakukan, melainkan berbagai macam faktor yang menjadi latar belakangnya. Karena itu, praktik yang secara langsung "menghukumi" seseorang yang mengalami sakit penyakit karena dosa merupakan kekeliruan dalam memahami Firman Tuhan dan juga masih melekat dalam dirinya konsep retribusi.

Menanggapi penderitaan tersebut. Berbagai respon diberikan supaya bisa tetap bertahan, kuat, bahkan keluar dari penderitaan itu. Illu memberikan berbagai respon yang dicatat oleh Alkitab tentang bagaimana sikap menanggapi penderitaan. Tentu yang utama adalah mengandalkan Tuhan (1 Kor. 1:9-11), penderitaan adalah bukti kasih Kristus (Flp. 1:29), mengucap syukur dan bersukacita (Flp. 4:4; 1 Tes. 5:18), dan menyadari bahwa penderitaan yang dihadapi pasti tidak melebihi kekuatan manusia (Illu, 2019). Hal ini ditegaskan oleh Hidayat yang memberikan gagasan Allah adalah Maha Pengasih dan Penyayang untuk meresponi penderitaan yang dihadapi manusia dari manapun asalnya (Hidayat, 2016). Respon ini juga perlu diarahkan kepada wahyu umum yang dinikmati oleh manusia, yaitu alam sebagai bagian yang tidak 
terpisahkan, dimana hukum dan hukum alam berjalan dengan beraturan. Konsep ini menimbulkan respon yang implementatif untuk menjaga lingkungan sebagaimana mestinya (Gunawan, 2017). Karenanya, jangan memahami bahwa Allah sedang menghukum aktif dalam penderitaan yang dihadapi manusia.

Peneliti menyoroti penderitaan dalam konteks masa kini (George Eldon Ladd menyebutnya sebagai The Already and The Not Yet), yaitu setelah masa Perjanjian Lama telah mengalami perubahan signifikan dalam konteks budaya Yahudi. Budaya Yahudi yang selalu menghubungkan penderitaan sebagai akibat dosa (hukum retribusi) diarahkan kepada panggilan karena mengikut Yesus dalam Perjanjian Baru, dan fakta kehidupan yang tidak bisa dihindarkan oleh siapa saja pada era postmodern ini. Perubahan pemikiran ini menurut hemat peneliti adalah prinsip yang perlu digemakan agar orang percaya tidak serta merta memandang penderitaan sebagai hukuman dari Allah. Namun, perlu juga dibuat keseimbangan dalam memaknai penderitaan sebagai hukuman dari Allah. Sebab jika melepas secara menyeluruh penderitaan sebagai hukuman dari Allah, manusia akan cenderung untuk tidak bersifat intropeksi diri. Alih-alih menekankan salah satu, peneliti berposisi untuk orang Kristen tidak terlalu cepat memberikan stigma atau label akan suatu bencana.

\section{Teologi Bertahan (Survival Theology) Gemma Tulud Cruz}

Gemma Tulud Cruz adalah dosen senior dan anggota institut agama dan penyelidikan kritis di Universitas Katolik Australia. Dia adalah penulis banyak publikasi tentang teologi bertahan hidup di tengah penderitaan akibat harus bermigrasi, termasuk didalamnya adalah Toward an Intercultural Theology of Migration: Pilgrims in the Wilderness dan Toward a Theology of Migration: Social Justice and Religious Experience. Lahir dan besar dalam peradaban Filipina, Cruz berkonsentrasi Pendidikan keagamaan. Setelah meraih gelar sarjana di Filipina yang berkonsentrasi dalam pendidikan Bahasa Inggris dan Agama, dia melanjutkan pendidikannya di bidang Studi Keagamaan. Selanjutnya, Cruz menyelesaikan Philosophy Doctornya dalam bidang Teologi dengan predikat cum laude, di Radboud Universiteit Nijmegen Belanda. Cruz menulis disertasinya tentang pekerja rumah tangga migran Filipina di Hong Kong. Cruz memiliki ketertarikan untuk membahas teologi Asia karena dianggap memiliki pendekatan yang berbeda dengan teologi Barat.

Cruz memberikan kontribusi penting bagi teologi migrasi. Itu konteks yang mendominasi sebagian besar pekerjaan dalam teologi migrasi adalah konteks AS-Meksiko perbatasan dan pada tingkat yang lebih rendah migrasi di Eropa dan Afrika (Yong, 2011). Cruz mengamati bahwa tuntutan pada menjaga iman seseorang - "iman pada diri mereka sendiri, pada orang lain, dan pada Tuhan" - adalah di antara yang paling tantangan penting bagi seorang migran, khususnya migran perempuan (Cruz, 2006). Di sini Cruz berpendapat untuk hasil yang luas dan terfokus untuk misi dalam konteks migrasi. Dia menekankan tanggung jawab gereja-gereja lokal di baik negara asal maupun negara tuan rumah untuk memastikan bahwa para migran "dilengkapi dengan disposisi dan keterampilan” yang dibutuhkan untuk pengalaman migrasi mereka (Cruz, 2010).

Cruz mengamati bahwa gereja lebih dari sekedar tempat perayaan, itu juga merupakan sarana utama untuk melawan penindasan; gereja adalah pusat keagamaan dan sosial, tempat perlindungan mereka di saat krisis dan rumah mereka ketika mereka ingin bersorak gembira (Cruz, 2006, 19-20). Itu sebabnya, harus ada upaya nyata sebagai refleksi dari pertanyaan "apakah keselamatan masa kini?" Jika menjadi percaya mendapatkan surga dan kesejahteraan, bagaimana dengan penderitaan yang silih berganti datang. Cruz pada dasarnya membawa keselamatan masa kini untuk memahami diri sebagai manusia seutuhnya. Dimana 
terdapat curahan perhatian terhadap kehidupan spiritual (dosa dan keselamatan mendapatkan surga), hakikat dan martabat manusia hidup, dan hak asasi. (Elwood, 2010).

Teologi yang diperkenalkan oleh Cruz adalah teologi bertahan hidup (survival theology) yang dibangun berdasarkan pengamatan pada orang Asia yang memiliki berbagai cara untuk bertahan hidup dalam berbagai situasi penderitaan. Cruz memberikan beberapa cara bertahan hidup yang dilakukan oleh orang Asia ketika hidup dalam realitas penderitaan. Pertama, orang Asia akan diam ketika penderitaan datang. Penemuan yang disampaikan Cruz seakan-akan bertentangan dengan ilmu psikologi yang menyatakan diam akan memperburuk masalah (Natawidjaja, 2019). Diam yang dimaksudkan oleh Cruz adalah menenangkan diri dengan perilaku kontemplatif untuk mengambil makna dari penderitaan atau kejadian yang tidak mengenakan terjadi. Dengan demikian, diam yang dilakukan bukan menyendiri dan menyalahkan diri, melainkan ingin memahami rencana Tuhan dibalik masalah yang dihadapi (Gemma Tulud Cruz, 2012). Dengan berdiam maka manusia dapat berpikir secara jernih dan sehat untuk mengetahui dan mendapatkan strategi untuk bagaimana keluar dari masalah yang dihadapi.

Kedua, menonton dan melakukan kegiatan yang menimbulkan humor dan tertawa. Humor dapat berasal dari mana saja, terkhusus kepada tindakan-tindakan yang tidak wajar dilakukan atau menyimpang. Hal-hal sederhana lainnya juga dapat menjadi humor yang membuat pendengar dan orang yang ikut dalam adegan humor itu tertawa. Cruz melihat kecenderungan orang Asia yang senang tertawa dengan segala fenomena yang dihadapinya, sehingga penderitaan bukan menjadi bahan untuk menangis (Gemma Tulud Cruz, 2012). Tidak bermaksud tidak peduli atau berempati terhadap masalah orang lain. Tertawa yang dimaksud adalah sukacita bersama-sama dalam mengarungi penderitaan. Tentu ini amat berlainan dengan disaster joke yang menyerang pihak lain akibat penderitaan yang dihadapi (Susanta \& Panuntun, 2020). Respon yang Cruz sampaikan amat berbeda dengan tradisi gereja selama ini. Kecenderungan anti-humor telah lama disampaikan oleh bapa Gereja karena berkaitan dengan kebencian dan kebodohan (Morreall, 2008). Bahkan Krisostomus menegaskan bahwa tertawa sama sekali tidak mengikuti teladan Yesus Kristus. Seharusnya orang percaya menangis ketika mengalami masalah (Halliwell, 2008). Pemikiran Cruz merefleksikan hidup yang dinikmati dengan rasa syukur bahwa Allah tetap sebagai pribadi yang memperhatikan umat-Nya yang mengalami penderitaan. Allah menunjukkan kepeduliannya dengan mengirimkan humor yang menyebabkan manusia tetap dapat tersenyum.

Ketiga, respon yang sering dilakukan oleh orang Asia adalah bercerita-cerita. Orang Asia terkenal dengan keramahannya kepada siapa saja. Senang berkumpul-kumpul untuk saling bercerita akan keadaan dan kondisi yang dialaminya (Gemma Tulud Cruz, 2014). Bercerita panjang yang ditemani dengan makanan dan minuman dapat membuat lupa segalanya yang sedang dihadapi. Lupa bukan berarti tidak mengingat penderitaan yang dialaminya, melainkan membuat otak lebih rileks sehingga selesai cerita, mereka akan lebih dewasa menghadapi masalah yang ada. Dengan berdiskusi keadaan pribadi kepada orang lain -tentunya yang dipercaya- menimbulkan kekuatan diri untuk memandang penderitaan dari perspektif yang berbeda. Diskusi membuat pemahaman semakin luas dan mendapatkan strategi penyelesaian dari orang lain.

Keempat, lagu dan tari yang umumnya dilakukan oleh kaum wanita (Gemma Tulud Cruz, 2012). Dalam artian negatif, tari dan lagu akan mengarah kepada tindakan alkoholisme dan kehidupan malam yang merusak. Tetapi, perspektif Cruz mengarah kepada ekspresi atau luapan diri terhadap penderitaan yang dilakukan dengan menari dan bernyanyi adalah pengeluaran kesedihan diri. Itu sebabnya, terdapat banyak karaoke dan jasa-jasa tempat bernyanyi lainnya. Menari mampu mengeluarkan amigdala yang membuat 
perasaan takut dan stress pada diri manusia dapat keluar. Menari juga ungkapan syukur dalam ibadah Yahudi akan eksistensi Tuhan dalam hidup umat-Nya.

Strategi bertahan hidup yang dipaparkan di atas menunjukkan secara jelas bahwa penelitian Cruz mengarah kepada tindakan yang berbeda dari orang Asia dalam menghadapi penderitaan. Selain itu, Cruz juga memberikan masukan bagaimana bertahan hidup dalam penderitaan adalah dengan membangkitkan kreativitas. Untuk seseorang keluar dari penderitaannya, penting untuk making a way of no way. Dalam konteks migrasi, Cruz banyak menemui para imigran wanita yang bekerja tidak memiliki kapasitas dan keterampilan yang tinggi. Benar-benar hanya sebagai seorang pembantu tanpa kreativitas. Padahal di beberapa tempat, mereka menjumpai tuan rumah yang terbuka dan mendukung pencapaian dari asisten rumah tangganya. Itu sebabnya, Cruz mendorong supaya gereja pengirim imigran ke negara lain, harus mempersiapkan dahulu kualitas dan keterampilan anggotanya. Barulah memberangkatkan mereka. Jangan tidak peduli dengan keterampilan yang mereka miliki, dan hanya menasehati untuk tetap percaya kepada Tuhan (Cruz, 2006).

Teologi bertahan hidup Asia adalah iman dan komunitas. Sebab bertahan hidup adalah sebuah cara untuk bertahan, baik secara individual atau komunal dalam keadaan tertindas dan agama memberi makna itu. Itu sebabnya, Cruz memberikan formula untuk menjaga iman seseorang dengan "keyakinan pada diri mereka sendiri, pada orang lain, dan pada Tuhan" (Cruz, 2006, 9-11). Kekuatan komunitas merengkuh seluruh cara-cara yang telah dipaparkan diatas. Tanpa adanya komunitas, maka ekspresi unik Asia tidak dapat tercurahkan dengan benar. Maksud tidak benar seperti, bercerita yang dilakukan bukan kepada komunitas yang mendukung untuk penyelesaian masalah, melainkan kepada orang-orang yang membawa dampak negatif.

Prinsip yang terutama dalam teologi bertahan hidup ala Cruz adalah dukungan Allah dalam keadaan tertindas dan melihat Allah adalah kebutuhan yang menyebabkan kepercayaan kepada Allah menjadi sempurna. Cruz menjelaskan bahwa Misi adalah insentif terbaik apabila direnungkan dengan cinta sehingga menimbulkan ketenangan hati karena telah menyentuh bagian terdalam manusia (Cruz, 2015). Realitas Allah tidak bisa dipisahkan untuk bertahan dalam penderitaan. Allah memberi kekuatan dan ketenangan yang melampaui segala akal sehingga umat percaya memiliki pengharapan yang tidak berkesudahan. Harapan terhadap masa depan yang lebih baik meskipun dalam kesulitan yang besar kental dalam pemikiran orang Asia. Penulis mengamini pemahaman ini karena sifat orang Asia yang menginginkan kehidupan lebih baik. Gairah ini berangkat dari cinta yang ditunjukkan dengan perubahan hidup bagi orang yang dicintainya. Orang Asia ingin orang yang dicintainya tidak mengalami kesulitan yang terjadi turun temurun. Kembali kepada domain dari teologi Cruz yang menyoroti perjuangan seorang migrasi. Dia menggambarkan mereka adalah seorang musafir yang berjuang dalam perjalanan untuk sampai ke tempat yang pasti. Perjalanan ini memaksa mereka untuk bertahan hidup apabila ingin tetap sampai tujuan. Karenanya ini adalah ini sebenarnya adalah perjalanan harapan yang berakar pada keberanian, diberdayakan oleh iman yang ulet, dan dipupuk oleh keinginan kuat dan kreatif untuk melawan.

\section{Kekristenan Indonesia dalam Masa Pandemi Covid-19}

Cruz secara khusus membahas mengenai penderitaan yang dialami dan dihadapi akibat dari imigrasi Filipina di Hongkong. Tetapi, konsep dan pemahaman ini dapat diterapkan dalam segala aspek penderitaan orang Asia. Dalam buku terbitan terbaru tahun 2021, Christianity Across Borders Theology and Contemporary Issues in Global Migration, Cruz mengaitkan penderitaan kaum imigran wanita dengan 
keadaan pandemi Covid-19. Pada bagian part pertama berbicara mengenai politik orang terpinggirkan dan identitas, Cruz memasukkan bab mengenai menuju kesembuhan, dimana pandemi covid-19 dan imigrasi adalah dua penderitaan yang memperlengkapi (Gemma Tulud Cruz, 2021). Itu sebabnya, penulis dapat secara langsung mengaitkan survival theology dalam konteks imigrasi kepada konteks penderitaan akibat Pandemi Covid-19.

Kekristenan Indonesia dapat mempraktekkan tindakan diam dirumah selama masa pandemi ini. Tentunya tidak sulit untuk melakukannya, sebab pemerintah telah mengeluarkan peraturan supaya masyarakat mengurangi mobilitas dan tetap melakukan berbagai kegiatan dari rumah. Dalam keadaan berdiam diri dirumah, umat Kristen dapat melakukan kegiatan membaca yang tentunya menambah pengetahuan dan kapasitas diri. Dia juga terkait dengan menantikan pertolongan Tuhan dan menenangkan diri. Ratapan 3:26 menuliskan bahwa Adalah baik menanti dengan diam pertolongan TUHAN. Demikian dengan Mazmur 131:2 yang menjelaskan Sesungguhnya, aku telah menenangkan dan mendiamkan jiwaku; seperti anak yang disapih berbaring dekat ibunya, ya, seperti anak yang disapih jiwaku dalam diriku.

Tertawa dan humor yang dipadukan dengan bercerita sebagai cara kedua dan ketiga bertahan dalam penderitaan dapat dilakukan dalam lingkup keluarga. Amsal 1:22 dengan eksplisit menegaskan bahwa hati yang gembira adalah obat yang manjur. Penulis kitab Amsal menuliskan hati sebagai sentral dari kegembiraan seseorang. Dalam bahasa Ibrani, hati menggunakan kata לִ (leb), mind, attention, consideration, understanding, will, heart. Kata-kata ini mengarah kepada sumber kehidupan manusia adalah berasal dari hati. Sedangkan kata gembira berasal dari wֵ: (samekha) yang berarti illed with joy or glad. Kata ini merujuk kepada sukacita yang tidak diatur oleh keadaan atau situasi, melainkan sebuah pilihan pribadi yang diekspresikan (EliciaIrawaty, 2020). Hati sebagai sumber jika diisi dengan sukacita yang bukan dari keadaan akan menjadi obat yang manjur. Penulis Amsal menggunakan frasa obat yang

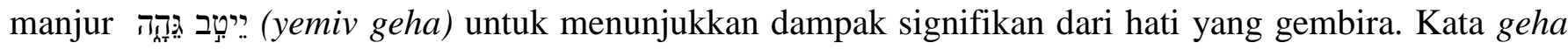
adalah penyembuhan yang terjadi secara menyeluruh. Dalam implementasi masa pandemi, penulis memotret peran keluarga (lagi) menjadi sentral (Hulukati, 2015). Keluarga membangun mezbahnya dan saling bercerita akan struggle yang dialami oleh masing-masing anggota dalam dimensi kehidupannya. Selanjutnya diskusi dibumbui dengan humor seperti saling roasting antara orang tua dan anak. Disinilah optimalisasi peran keluarga muncul di bagian utama. Dengan optimalisasi canda tawa dan diskusi didalamnya, maka imun dari masing-masing anggota akan baik (Santika, 2020). Hal ini tidaklah berlebihan, sebab sumber diskusi dan humor sebelum pandemi dengan mudah didapatkan dimana saja karena keramahan orang Asia. Tetapi, dengan penetapan jaga jarak dan menghindari kerumunan, maka mustahil hal itu terwujud.

Tindakan keempat dengan bernyanyi dan menari secara komunal akan sulit dilakukan selama masa pandemi ini. Itu sebabnya, gereja dapat mempersiapkan fasilitas memuji dan menyembah melalui media virtual. Hal ini sudah banyak dilakukan gereja ketika mengganti ibadah secara onsite kepada online. Lagulagu yang dibawakan dipilih dengan kehidupan secara nyata. Tetapi untuk urusan menari, belum ada gereja yang memberi wadah. Penulis berpendapat bahwa aplikasi yang sedang booming karena fitur-fiturnya yang menarik untuk menari, yaitu tik-tok dapat menjadi solusi. Orang Kristen Asia, khususnya Indonesia tidak perlu takut untuk menggunakan media sosial ini sebagai sarana menari bahkan tertawa. Meskipun masih pro-kontra, tetapi penulis berpendapat bahwa tiktok adalah media yang baik sebagai wadah menari.

Cruz mendorong supaya melakukan Creative Resistance dalam menghadapi masalah. Kajiannya terhadap imigran dari Filipina ke Hong Kong yang mengalami penindasan dan kekerasan dikarenakan kurangnya kreativitas dari wanita imigran Filipina. Era Pandemi dapat menjadi peluang untuk seluruh orang 
eksis dalam segala bidang. Kemajuan teknologi dengan mudah memperkenalkan produk yang dibuat. Menjadi pertanyaan, apakah kita memiliki produk yang dapat dipasarkan? Disinilah Cruz mendorong kreativitas untuk dapat bertahan. Umat percaya Indonesia dapat menggunakan media sosial yang ada untuk berkarya dan memberikan dukungan kepada setiap orang yang mengalami penderitaan akibat Covid-19. Misalnya, membuat video singkat untuk mendukung para medis dan garda terdepan lainnya. Namun, creative resistance ini juga dapat diaplikasikan dengan berjualan secara online, membuat desain grafis, dan kreatifitas lainnya. Kreativitas ini lahir apabila orang percaya memiliki hubungan dengan sumber kreativitas, yaitu Allah. Karena itu, umat percaya seharusnya mampu tetap bertahan karena memiliki ideide yang cerdas untuk mencari "kesempatan dalam kesulitan."

Sebagai negara-negara yang pluralistik, kekristenan Indonesia mesti mempraktekkan etika Solidaritas (Setyobekti et al., 2021). Bagian dari masalah ketidakadilan terjadi karena orang yang memiliki hak istimewa berpikir bahwa mereka pantas mendapatkannya, sambil berasumsi bahwa yang kurang beruntung pasti punya sesuatu salah dengan mereka atau mereka tidak akan masuk kesulitan yang mereka hadapi. Tugas awal dari etika solidaritas adalah mengakui apa itu hak istimewa, dan untuk sebagian besar, mengetahui bahwa mereka memiliki hak istimewa (Peters, 2014). Disini penting untuk melakukan simbiosis mutualisme. Clarke menyoroti bahwa teologi Asia begitu mudah untuk berinteraksi dengan pihak beragama lain (Clarke, 2012). Cruz dalam sebuah penelitian pada masa pandemi memotret bagaimana solidaritas di Amerika amat memprihatinkan. Ketika seseorang terpapar pandemi Covid-19, bukan pertolongan yang diberikan, melainkan kekerasan secara verbal dan fisik yang menyebabkan korban dirawat di unit Gawat Darurat (Cruz, 2019). Tindakan ini sungguh berbeda dengan Indonesia yang saling membantu dalam kesulitan. Penderitaan justru dipandang sebagai momentum untuk membawa persatuan tanpa membeda-bedakan suku, kelas social, Pendidikan, bahkan Agama. Penderitaan merobohkan temboktembok pembatas yang selama ini terbangun karena keadaan nyaman dan aman yang dialami.

Keimanan akan Yesus dan pengharapan akan kabar baik didepan dalam menghadapi penderitaan, mesti berjalan lurus dengan rasa persaudaraan dan solidaritas antar sesama bangsa. Saling membantu untuk meringankan beban orang lain adalah tindakan real yang harus dilakukan dalam momentum ini. Gereja dapat bekerja sama dengan institusi pemerintahan untuk menanggulangi permasalahan ini. Hal ini dilakukan oleh My Home Bekasi yang digagas oleh Agus dan beberapa pemuda lainnya. Kerja sama ditunjukkan dengan memberikan paket sembako kepada masyarakat yang melakukan isolasi mandiri (Isoman) dan mendirikan dapur umum. Sudah semestinya seluruh gereja juga melakukan ini (Sianturi, 2021). Gereja harus menjadi miskin dalam kebersamaan melewati penderitaan akibat pandemi.

\section{Kesimpulan}

Keselamatan pada masa kini berkaitan dengan kemampuan bertahan hidup di masa yang sulit. Hal ini membawa makna baru bahwa kehidupan semestinya tidak dipahami sebagai penderitaan tanpa kenikmatan di dalamnya. Dengan menganalisis pemikiran Cruz mengenai survival theology di tengah penderitaan, dapatlah dilakukan tindakan prakstis berdiam dalam kontemplatif. Diam yang menghasilkan pemahaman dan pemaknaan akan masalah yang terjadi. Optimalisasi peran keluarga juga menjadi tindakan gereja untuk menyiapkan wadah humor dan tertawa, serta bercerita akan masalah yang ada. Menggunakan media sosial, seperti tik-tok dapat menjadi wadah mengekspresikan tari dan bernyanyi sebagai cara orang Asia bertahan hidup. Cruz mendorong kreativitas untuk dapat bertahan dan solidaritas dalam pluralitas bangsa. Kedua hal ini menjadi tugas gereja dalam memperlengkapi jemaat. Jemaat dibawa masuk kepada 
dimensi bahwa pandemi covid-19 adalah momentum untuk menolong orang lain dalam kesusahan. Kembali kepada pertanyaan, siapakah Tuhan bagi kita? Realitas ini semestinya dijawab sebagai sumber kekuatan, pertolongan, dan penghiburan yang sejati dalam masa sulit. Tuhan adalah pribadi yang mengontrol kejadian yang dialami umat manusia. Dan Tuhan juga pribadi yang membukakan pemikiran orang percaya akan mengapa dia tetap eksis di dunia ini setelah diselamatkan.

\section{Referensi}

Ahn, I. (2019). Theology and Migration. Brill Research Perspectives in Theology, 3(2), 1-108. https://doi.org/10.1163/24683493-12340006

Aritonang, J. S. (2018). Teologi-Teologi Kontemporer. BPK Gunung Mulia.

Baker, D. E. (2008). Mari Mengenal Perjanjian Lama. BPK Gunung Mulia.

Boersema, J. A., Venema, H., \& Indrasmoro, Y. M. (2015). Berteologi Abad XXI: Menjadi Kristen Indonesia di Tengah Masyarakat Majemuk. Literatur Perkantas.

Bruce, F. F. (2013). Ucapan Yesus Yang Sulit. SAAT.

Christiastuti, N. (2021). matian Corona Melonjak, India Kekurangan Pasokan Kayu untuk Kremasi. DetikNews.

Clarke, S. (2012). The task, method, and content of Asian Theology. In P. J. Rufus (Ed.), Asian Theology on The Way, Christianity, Culture, and Context. SPCK.

Cruz, G. T. (2004). Migration in the Asian Region: Retrospect and Prospects. In R. Fornet-Betancourt (Ed.), Migration and Interculturality: Theological and Philosophical Challenges. Missionswissenschaftliches Institu Missio.

Cruz, G. T. (2006). Faith on the Edge: Religion and Women in the Context of Migration. Feminist Theology, 15(1), 9-25. https://doi.org/10.1177/0966735006068847

Cruz, G. T. (2010). Expanding the Boundaries, Turning Borders into Spaces: Mission in the Context of Contemporary Migration. In O. Kalu, P. Vethanayagamony, \& E. K.-F. Chia (Eds.), Mission After Christendom: Emergent Themes in Contemporary Mission (pp. 71-83). John Knox Press.

Cruz, G. T. (2015). Chapter five of Evangelii Gaudium: Spirit-filled evangelizers. International Review of Mission, 104(2), 187-192. https://doi.org/10.1111/irom.12094

Cruz, G. T. (2019). An Unfinished Journey or a Journey Without an End?: Asian American Catholics and Harmony and Interculturality in the American Catholic Church.

EliciaIrawaty, F. (2020). Dampak Hati yang Gembira Terhadap Kesehatan Jasmani : Eksposisi Amsal 17:22. Logia: Jurnal Teologi Pentakosta, 1(2), 113-114.

Elwood, D. J. (2010). Teologi Kristen Asia: Tema-tema Yang Tampil ke Permukaan. BPK Gunung Mulia. Gemma Tulud Cruz. (2012). Between a rock and a hard place: An Asian Theology Survival. In Peniel Jesudason Rufus (Ed.), Asian Theology on The Way, Christianity, Culture, and Context (pp. 75-82). SPCK.

Gemma Tulud Cruz. (2014). Toward a Theology of Migration: Social Justice and Religious Experience. Palgrave Macmillan.

Gemma Tulud Cruz. (2021). Christianity Across Borders Theology and Contemporary Issues in Global Migration. Routledge.

Gunawan, E. (2017). Meneropong Makna Penderitaan Manusia. Veritas : Jurnal Teologi Dan Pelayanan, $16(30), 17-32$.

Halliwell, S. (2008). Greek Laughter: A Study of Cultural Psychology from Homer to Early Christianity. 
CUP.

Hasiholan, A. M. (2020). Studi Komparatif Terhadap Pemahaman Teologi Reformed dengan Pemahaman Teologi Pentakosta tentang Natur Manusia. Pneumata, 1(1), 54-71.

Heyer, K. E. (2020). Migrants Feared and Forsaken: A Catholic Ethic of Social Responsibility. Interdisciplinary Journal for Religion and Transformation in Contemporary Society, 6(1), 158-170. https://doi.org/10.30965/23642807-00601010

Hidayat, E. A. (2016). Iman di Tengah Penderitaan: Suatu Inspirasi Teologis-Biblis Kristiani. Melintas, 33(3), 285-308.

Hulukati, W. (2015). Peran Lingkungan Keluarga terhadap Perkembangan Anak. Musawa, 7(2), 265-282. Illu, J. (2019). Penderitaan Dalam Perspektif Alkitab. Jurnal Luxnos, 5(2), 24-33.

Keputusan Presiden RI. (2020). Keppres No 12 Tahun $2 \mathrm{O} 2 \mathrm{O}$ Tentang Penetapan Bencana Nonalam Penyebaran Corona Virus Disease 2019 Sebagai Bencana Nasional. Fundamental of Nursing, 01, 12.

Khoerunisa, N., \& Noorikhsan, F. F. (2021). Perbandingan Tata Kelola Penanganan Pandemi Covid 19 di Indonesia dan India. Journal of Political Issues, 2(2), 89-101. https://doi.org/10.33019/jpi.v2i2.36

Limasaputra, A. D. (2018). Memandang Penderitaan Melalui Perspektif The Already and The Not Yet dari Rasul Paulus. Veritas: Jurnal Teologi Dan Pelayanan, 17(1), 43-60. https://doi.org/10.36421/veritas.v17i1.305

Morreall, J. (2008). Philosophy and Religion. In V. Raskin (Ed.), The Primer of Humor Research. Mouton de Gruyter.

Nasution, D. A. D., Erlina, E., \& Muda, I. (2020). Dampak Pandemi COVID-19 terhadap Perekonomian Indonesia. Jurnal Benefita, 5(2), 212. https://doi.org/10.22216/jbe.v5i2.5313

Natawidjaja, R. (2019). Konseling Kelompok, Konsep Dasar dan Pendekatan. Rizqi Press.

Pasulu, A. (2016). Teologi Asia. Makalah Pada mata Kuliah Perkembangan Teologi Kontemporer.

Peters, R. T. (2014). Solidarity Ethics: Transformation in a Globalized World. Fortress Press. https://doi.org/10.1111/erev.12123

RI, P. (2020). PP REPUBLIK INDONESIA NOMOR 21 TAHUN 2020 TENTANG PEMBATASAN SOSIAL BERSKALA BESAR DALAM RANGKA PERCEPATAN PENANGANAN CORONA WRUS DISEASE 2019 (COVID-Ig) DENGAN. 2019(022868), 8.

Santika, I. G. N. (2020). Optimalisasi Peran Keluarga Dalam Menghadapi Persoalan Covid-19: Sebuah Kajian Literatur. Jurnal Ilmiah Ilmu Sosial, 6(2), 127-137.

Sasongko, T. H. (2021). Penyebab Kasus Covid-19 dan Kematian di Asia Tenggara Meningkat Tajam Artikel ini telah tayang di Kompas.com dengan judul "Penyebab Kasus Covid-19 dan Kematian di Asia Tenggara Meningkat Tajam. Kompas.Com.

Septiani, A. (2021). WHO Ungkap Penyebab Tsunami COVID-19 di India. DetikHealth.

Setyobekti, A. B., Kathryn, S., \& Sumen, S. (2021). Implementasi Nilai-nilai Bhineka Tunggal Ika dalam Membingkai Keberagaman Pejabat Gereja Bethel Indonesia di DKI Jakarta. SOTIRIA (Jurnal Theologia Dan Pendidikan Agama Kristen), 4(1), 1-10. https://doi.org/10.47166/sot.v4i1.29

Sianturi, M. (2021). My Home Bekasi MHB bagikan 250 paket sembako untuk warga yang terdampak corona dalam aksi Bekasi The City of Harmony. Efnews.Id.

Susanta, Y. K., \& Panuntun, D. F. (2020). Tinjauan Etika Kristen Atas Fenomena Disaster Joke Terkait Pandemi Covid-19. HARVESTER: Jurnal Teologi Dan Kepemimpinan Kristen, 5(1), 14-27. 
https://doi.org/10.52104/harvester.v5i1.20

Tim CNN Indonesia. (2021). Daftar Negara Asia dengan Lonjakan Covid-19 dalam Sepekan. CNN Indonesia.

Tong, S. (1999). Mengenal Kehendak Allah. Momentum.

Velarosdela, R. N. (2020). 11 Bulan Pandemi Covid-19, Pelaku Usaha Gulung Tikar hingga Pegawai Bioskop Jemput Bola Cari Penonton. Kompas.Com.

Wilfred, F. (Ed.). (2014). The Oxford Handbook of Christianity in Asia. Oxford University Press.

Yanwardhana, E. (2021). Hari Ini Kasus Covid-19 di RI dan Malaysia Sama-Sama Rekor! CNBC Indonesia.

Yewangoe, A. A. (1996). Teologi Crucis di Asia: Pandangan-pandangan orang Kristen di Asia mengenai Penderitaan dalam Kemiskinan dan Keberagaman di Asia. BPK Gunung Mulia.

Yong, A. (2011). An Intercultural Theology of Migration: Pilgrims in the Wilderness - By Gemma Tulud Cruz. Religious Studies Review, 37(1), 29-40.

Zaluchu, S. E. (2020). Strategi Penelitian Kualitatif dan Kuantitatif Di Dalam Penelitian Agama. Evangelikal: Jurnal Teologi Injili Dan Pembinaan Warga Jemaat. https://doi.org/10.46445/ejti.v4i1.167

Zaluchu, S. E. (2021). Human Suffering and Theological Construction of Suffering. Evangelikal: Jurnal Teologi Injili Dan Pembinaan Warga Jemaat, 5(2), 127. https://doi.org/10.46445/ejti.v5i2.369 